\title{
TEACHERS' OPINIONS ON PROFESSIONAL SUPPORT MEASURES FOR NOVICE TEACHERS IN LATVIA
}

\author{
Anda Grinfelde ${ }^{1}$, Inga Vanaga ${ }^{2}$, \& Liga Paula ${ }^{1}$ \\ ${ }^{1}$ Institute of Social Science and Humanities, Latvia University of Life Sciences and Technologies (Latvia) \\ ${ }^{2}$ Latvian Trade Union of Education and Science Employees (Latvia)
}

\begin{abstract}
Retention of teachers in education system is a serious problem in Latvia. This is a challenging issue, especially for novice teachers. Professional support measures such as mentoring, in-service training or emotional support are crucial for novice teachers to remain and continue working in school. The aim of this research is to explore opinions of Latvian teachers about professional support measures that are both available and needed to be introduced for novice teachers. This paper presents a part of the research results which were obtained during an on-line survey $(\mathrm{N}=1258)$ conducted by the Latvian Trade Union of Education and Science Employees in 2018. The questionnaire comprised the statements on following measures of professional support: methodological, financial, material and technological. The statements were assessed by using 5-point symmetric Likert scale (strongly agree, slightly agree, neither agree nor disagree, slightly disagree, strongly disagree). The results witness about regional disparities mainly between the capital city Riga and other regions: there are statistically significant $(p<0.05)$ differences in opinions of the teachers representing different regions of the country. The respondents agree that there is a lack of well-structured and uniform support system for novice teachers at national level. In many schools a mentoring is not provided at all, or mentoring is not a paid activity for those who support novice teachers. In general, the teachers are positive about availability of an emotional support and in-service training in the school they work. The most critical opinions are about material and financial support that novice teachers can access. The authors conclude that different professional support measures are available for novice teachers in Latvia, however, there is no support system in place to address which functions and support measures should be implemented at national, municipal or school level. Policy makers should focus on national teachers' support guidelines which would allow schools to ensure the most appropriate environment for novice teachers so that they would like to continue their careers in teaching profession.
\end{abstract}

Keywords: Mentoring, novice teachers, professional support.

\section{Introduction}

First years of teaching are the most determining in a teacher's professional life influencing, for example, job satisfaction and the length of career. Understanding and definitions of a novice teacher are ambiguous. In most of the studies, a novice teacher is considered as the one with less than three years of teaching experience (e.g. Huberman, 1993; Petty, Good, \& Putman, 2016), whereas, for example, in TALIS 2018 survey a novice teacher is defined as an educator with less than 5 years of in-service experience (OECD, 2019). As it has been revealed in previous studies (e.g. Buchanan et al., 2013; Ingersoll, Merrill, \& May, 2014), many novice teachers leave teaching soon after their first in-service experience. Retention of educators, especially novice teachers, in education system is a serious problem in Latvia as well as in many other countries. According to Eisenschmidt, beginning teachers in school need support in professional, social and personal dimensions (Eisenschmidt, 2006). It means that teachers need to acquire their roles, develop self-confidence, professional skills and knowledge as well as become members of a school community through integration into a school and profession in general. Colleagues can help to understand internal norms, values, and structure of a school, and more experienced teachers normally contribute to developing professional identity of novice teachers and their teaching approaches. Most of the novice teachers face so called 'reality shock' (Blakley, 2006), because their expectations are often confronted by reality when working in the real classroom changes their initial conceptions and own philosophy. Successful induction programmes such as mentoring and nationally or locally organized 
support systems are offered to strengthen coping ability of novice teachers. In different countries newly qualified teachers are offered different support (European Commission/EACEA/ Eurydice, 2015; Parker, 2010); lack of support is often reported as one of the factors influencing teacher's professional future. In almost two-thirds of the countries in Europe beginning teachers have access to structured induction phases of many different organizational patterns, however, Latvia is among those countries where the induction phase for fully qualified teachers does not exist (European Commission/EACEA/Eurydice, 2015) even though mentoring in Latvia is available. Novice teachers who had a mentor have better organizational skills and they cope with their responsibilities more easily (Fletcher \& Mullen, 2012) what in turn leads to greater possibility of teacher retention in a school (Freiman-Namser, 2001; Kelley, 2004). According to TALIS 2018 survey, school leaders in all OECD countries believe that mentoring is important for both teachers' work and students' performance; nevertheless, only $22 \%$ of novice teachers in OECD countries and 16\% in Latvia have had a mentoring (OECD, 2019). The most widespread types of professional development in OECD countries are courses and seminars. In Latvia, 95\% of teachers have participated in that kind of activities, and $61 \%$ of the teachers have been involved in coaching activities (OECD, 2019). Still, the teachers have pointed out that in certain areas an offer of professional development opportunities should be improved and expanded, for example, there is a demand for additional knowledge and skills in communication and information technologies, teaching in multicultural and multi-language environment, and teaching children with special needs. From all above mentioned, Latvian teachers consider improved skills in information technologies as the most required. In general, according to the OECD data teachers in Latvia are satisfied with their professional development and $89 \%$ of them admit its practical usefulness.

Professional support measures such as mentoring, in-service training or emotional support are crucial for novice teachers to remain and continue working in school. Other measures of professional support such as financial, material, technological, methodological, and societal are also important. The aim of this research is to explore opinions of Latvian teachers about professional support measures that are both available and needed to be introduced for novice teachers.

\section{Research methodology}

This paper focuses on support for novice teachers by presenting a part of the research results which were obtained during an on-line survey conducted by the Latvian Trade Union of Education and Science Employees (LIZDA) in November, 2018. The questionnaire comprising statements on methodological, financial, material, and technological measures of professional support was developed and posted on the webpage visidati.lv. Information about the survey was disseminated via LIZDA homepage, trade union's member organizations in schools, social media, and website eklase.lv. The respondents were offered to assess the statements by using symmetric 5-point Likert scale (strongly agree, slightly agree, neither agree nor disagree, slightly disagree, strongly disagree). The research was conducted according to the methodological and ethical principles of the online survey (Toepoel, 2015). The data were processed and presented solely in an aggregated way thus ensuring anonymity of the respondents.

The research sample was made of 1258 teachers representing all five statistical regions of Latvia: Vidzeme (25\%), Kurzeme (15\%), Zemgale (18\%), Latgale (24\%) and Riga region (18\%). More than half of the participants $(68 \%)$ are LIZDA members. Most of the respondents $(60 \%)$ represent rural municipalities, whereas $40 \%$ are from cities. Among the respondents, $94 \%$ are women and $6 \%$ are men. The respondents represent all levels of general education system in Latvia (preschool, elementary school, primary school, secondary school) and positions (e.g. teachers, school leaders); they are with different seniority and represent different age groups.

Standard deviation (SD) and mean (M) was calculated for the descriptive analysis of quantitative data by using statistical program SPSS (Statistical Package for Social Science v21). Independent samples t-test was calculated to analyse differences in opinions of the respondents representing different regions of Latvia.

\section{Results}

The survey results are outlined according to the statement groups related to methodological, financial, material, and technological measures of professional support. Generally speaking, the results show regional disparities mainly between the capital city Riga and other regions: there are statistically significant $(p<0.05)$ differences in opinions of the teachers representing different regions of the country. For example, contrary to the comparison of all other regions, there are statistically significant differences $(p<0.05)$ in teachers' opinions representing Riga and Latgale regions in assessment of importance of all 
support measures: methodological support (Riga $\mathrm{M}=2.24$; Latgale $\mathrm{M}=1.97$ ), financial support (Riga $\mathrm{M}=1.90$; Latgale $\mathrm{M}=1.92$ ), material and technological support (Riga $\mathrm{M}=2.11$; Latgale $\mathrm{M}=2.05$ ). Methodological support as very important was mostly emphasised by the teachers in Latgale $(51 \%)$ and Kurzeme (47\%) whereas material and technological support was mostly assessed as the most significant by the respondents in Latgale region $(43 \%)$. This can be partially explained by different regional socio-economic situation, wealth of local municipalities, and other specifics such as number of pupils in the classroom, workload and age of teachers.

As already mentioned previously, mentoring and support of more experienced colleagues is crucial for novice teachers to remain in teaching profession after their first years in school. Regarding integrated methodological support, the survey respondents agreed that there is a lack of well-structured and uniform support system for novice teachers at national level. As research results reveal, mentoring is not provided in many schools. This was indicated by $26.2 \%$ of the respondents while $13.2 \%$ of the respondents were not even informed about availability of mentoring in their schools as they could not answer this question. $44 \%$ of the teachers admitted that mentoring is not a paid activity for those colleagues who support novice teachers and $51.7 \%$ pointed out that teaching and regular workload for mentors is not decreased due to mentoring responsibilities. That in turn does not motivate teachers of greater seniority to become mentors. Another challenge is providing a mentor of the same school subject what novice teacher delivers. $78.4 \%$ of the respondents agreed (strongly agreed or slightly agreed) that mentoring for novice teachers is available in their schools during their first year of in-service. In general, the teachers were positive about availability of emotional support and in-service training in the school they worked. Opinions of the respondents on additional knowledge that novice teachers need are shown in the Table 1.

Table 1. Statements in the questionnaire on additional knowledge that novice teachers need in starting their careers.

\begin{tabular}{|l|c|c|c|c|c|c|c|c|c|c|c|c|}
\hline \multirow{2}{*}{$\begin{array}{c}\text { Additional knowledge/ support } \\
\text { that novice teachers need }\end{array}$} & \multicolumn{2}{|c|}{$\begin{array}{c}\text { Strongly } \\
\text { agree }\end{array}$} & \multicolumn{2}{|c|}{$\begin{array}{c}\text { Slightly } \\
\text { agree }\end{array}$} & \multicolumn{2}{c|}{$\begin{array}{c}\text { Neither } \\
\text { agree nor } \\
\text { disagree }\end{array}$} & \multicolumn{2}{|c|}{$\begin{array}{c}\text { Slightly } \\
\text { disagree }\end{array}$} & \multicolumn{2}{c|}{$\begin{array}{c}\text { Strongly } \\
\text { disagree }\end{array}$} & \multicolumn{2}{c|}{ No opinion } \\
\cline { 2 - 15 } & No & $\%$ & No & $\%$ & No & $\%$ & No & $\%$ & No & $\%$ & No & $\%$ \\
\hline $\begin{array}{l}\text { Mentoring on the basis of } \\
\text { respective regulations in every } \\
\text { school }\end{array}$ & 545 & 43.3 & 413 & 32.8 & 126 & 10.0 & 43 & 3.4 & 18 & 1.4 & 113 & 9.0 \\
\hline $\begin{array}{l}\text { Knowledge on rights and } \\
\text { responsibilities of teachers, } \\
\text { parents and children }\end{array}$ & 632 & 50.2 & 401 & 31.9 & 101 & 8.0 & 24 & 1.9 & 12 & 1.0 & 88 & 7.0 \\
\hline $\begin{array}{l}\text { Knowledge on better cooperation } \\
\text { with colleagues in a school }\end{array}$ & 485 & 38.6 & 453 & 36.0 & 170 & 13.5 & 45 & 3.6 & 17 & 1.4 & 88 & 7.0 \\
\hline $\begin{array}{l}\text { Knowledge on establishing } \\
\text { positive communication with } \\
\text { pupils and their parents }\end{array}$ & 576 & 45.8 & 460 & 36.6 & 106 & 8.4 & 26 & 2.1 & 15 & 1.2 & 75 & 6.0 \\
\hline $\begin{array}{l}\text { Knowledge on how to prepare } \\
\text { teaching materials effectively }\end{array}$ & 591 & 47.0 & 430 & 34.2 & 116 & 9.2 & 24 & 1.9 & 19 & 1.5 & 78 & 6.2 \\
\hline
\end{tabular}

The survey revealed more critical opinions about material, technical and financial support that novice teachers can access. The teachers were asked to assess the statements related to remuneration and impact of the lower salary rate on the motivation of young people to engage in teaching profession. Nearly all teachers agreed $(90 \%)$ that the lowest rate of wages for teachers set out in the regulatory enactments does not increase the prestige of the profession ( $92 \%$ of Riga teachers supported this statement). They also believed that the salary rate of the teacher cannot be lower than the average salary in the country, multiplied by a factor of 1.2 (93\% of Riga and $94 \%$ of Vidzeme respondents). Regarding this statement, opinions of teachers in Riga and Latgale regions differ significantly $(p<0.05$, Riga $\mathrm{M}=1.36$, Latgale $\mathrm{M}=1.55$ ), as well as those represented by the respondents from Riga and Zemgale regions ( $\mathrm{p}<0.05$, Riga $\mathrm{M}=1.36$, Zemgale $\mathrm{M}=1.46$ ). In comparison to the respondents from other regions, the teachers from Vidzeme region more frequently strongly agreed or slightly agreed (97\%) that teacher remuneration does not motivate young people to choose a job in this profession. Zemgale teachers more often $(81 \%)$ than teachers in the country on average $(75 \%)$ agreed with the statement that when students with special needs are integrated in general education institutions, teachers are not paid for any additional duties. Regarding this statement, regions of Riga and Latgale have statistically significant differences $(\mathrm{p}<0.05$, Riga $\mathrm{M}=1.36$, Latgale $\mathrm{M}=1.64)$. 
In Latgale, teachers more often (64\%) than average in Latvia (58\%) strongly agreed and slightly agreed that the costs of their professional development activities were covered by themselves during the period of the last three years. The regions of Riga and Latgale, contrary to the comparison of all other regions, had statistically significant differences $(\mathrm{p}<0.05$, Riga $\mathrm{M}=2.87$, Latgale $\mathrm{M}=2.42)$ regarding this statement. Normally in Latvia costs of the seminars and professional development courses for teachers are covered by municipalities. If this is mostly done by teachers themselves, it indicates on limited possibilities of municipalities.

In relation to the already available support measures, opinions of the respondents are presented in the Table 2. It is obvious that in most of the schools, particular material and financial support measures are rather poorly provided.

Table 2. Statements in the questionnaire on availability of support measures for novice teachers.

\begin{tabular}{|c|c|c|c|c|c|c|c|c|c|c|c|c|}
\hline \multirow{2}{*}{$\begin{array}{l}\text { Availability of support } \\
\text { measures at school / } \\
\text { municipality level }\end{array}$} & \multicolumn{2}{|c|}{$\begin{array}{l}\text { Strongly } \\
\text { agree }\end{array}$} & \multicolumn{2}{|c|}{$\begin{array}{c}\text { Slightly } \\
\text { agree }\end{array}$} & \multicolumn{2}{|c|}{$\begin{array}{c}\text { Neither } \\
\text { agree nor } \\
\text { disagree }\end{array}$} & \multicolumn{2}{|c|}{$\begin{array}{l}\text { Slightly } \\
\text { disagree }\end{array}$} & \multicolumn{2}{|c|}{$\begin{array}{l}\text { Strongly } \\
\text { disagree }\end{array}$} & \multicolumn{2}{|c|}{ No opinion } \\
\hline & No & $\%$ & No & $\%$ & No & $\%$ & No & $\%$ & No & $\%$ & No & $\%$ \\
\hline $\begin{array}{l}\text { Freely available methodological } \\
\text { materials }\end{array}$ & 236 & 18.8 & 363 & 28.9 & 236 & 18.8 & 208 & 16.5 & 145 & 11.5 & 70 & 5.6 \\
\hline $\begin{array}{l}\text { Professional development courses } \\
\text { and seminars }\end{array}$ & 635 & 50.5 & 406 & 32.3 & 81 & 6.4 & 20 & 1.6 & 18 & 1.4 & 98 & 7.8 \\
\hline $\begin{array}{l}\text { Emotional support provided by } \\
\text { senior colleagues }\end{array}$ & 431 & 34.3 & 508 & 40.4 & 144 & 11.4 & 47 & 3.7 & 27 & 2.1 & 101 & 8.0 \\
\hline $\begin{array}{l}\text { Additional and paid working time } \\
\text { for preparation teaching materials }\end{array}$ & 57 & 4.5 & 62 & 4.9 & 166 & 13.2 & 132 & 10.5 & 486 & 38.6 & 355 & 28.2 \\
\hline Video training for getting started & 34 & 2.1 & 10 & 3.0 & 163 & 13.0 & 119 & 9.5 & 503 & 40.0 & 369 & 29.3 \\
\hline $\begin{array}{l}\text { Service apartments provided by } \\
\text { local municipality }\end{array}$ & 56 & 4.5 & 102 & 8.1 & 120 & 9.5 & 82 & 6.5 & 482 & 38.3 & 416 & 33.1 \\
\hline $\begin{array}{l}\text { Transport compensation provided } \\
\text { by local municipality }\end{array}$ & 70 & 5.6 & 58 & 4.6 & 117 & 9.3 & 81 & 6.4 & 569 & 45.2 & 363 & 28.9 \\
\hline
\end{tabular}

Regarding provision of health insurance there are statistically significant differences between the regions of Riga and Latgale $(\mathrm{p}<0.05)$; in the region of Riga $75 \%$ of the respondents have received health insurance, while in Latgale there were only $21 \%$, which is the least result in comparison to all other regions. Approximately $40-50 \%$ of teachers in all regions had free catering in school; there were no statistically important regional differences in this.

More than half of the respondents believed that novice teachers should have lower work load at the beginning of their career (28.7\% strongly agreed and $29.7 \%$ slightly agreed) in order to complete all responsibilities duly and professionally.

In general, the survey results revealed that in the regions of Latgale and Riga teachers were more likely to assess all forms of professional support as important, so they felt the need for aid. There are no statistically significant differences in opinions of trade union members and other respondents.

\section{Discussion and conclusions}

The authors conclude that different professional support measures are available for novice teachers in Latvia, however, there is no support system in place to address which functions and support measures should be implemented at national, municipal and school level. The TALIS 2018 survey indicated following the most common priorities for policy intervention reported by teachers: 1) reducing class sizes; 2) improving teacher salaries; 3) offering high-quality professional development for teachers, and 4) reducing teachers' administration load (OECD, 2019). Considering these priorities, Latvian policy makers also should focus on implementation teachers' support guidelines at national level. This would allow schools to ensure the most appropriate environment for novice teachers so that they would like to continue their careers in teaching profession.

Even though mentoring is available, still many teachers lack this opportunity. Also, teachers of greater seniority may lack appropriate support and motivation to become mentors as often mentoring is not a paid activity and is not included in teacher workload. Material and financial support measures such as transport compensation, increased remuneration, adequate professional development seminars would increase retention of novice teachers into education system. 


\section{References}

Blakley, L. (2006). Rites of passage: The role of induction in the enculturation of beginning teachers. University of New Orleans Theses and Dissertations. Paper 379.

Buchanan, J., Prescott, A., Schuck, S., Aubusson, P., Burke, P., \& Louviere, J. (2013). Teacher retention and attrition: Views of early career teachers. Australian Journal of Teacher Education, 38 (3), 112-129.

Eisenschmidt, E. (2006). Kutseaasta kui algaja õpetaja tugiprogrammi rakendamine Eestis. [Implementation of induction year for novice teachers in Estonia] (PhD dissertation, Tallinna Ülikooli Kirjastus). Retrieved from https:/www.etis.ee/Portal/Publications/Display/6c7d17921df0-45f2-8e96-ad5973d38346?lang=ENG

European Commission/EACEA/Eurydice (2015). The teaching profession in Europe: Practices, perceptions, and policies. Eurydice Report. Luxembourg: Publications Office of the European Union.

Feiman-Nemser, S. (2001). From preparation to practice: Designing a continuum to strengthen and sustain teaching. Teachers College Record, 103(6), 1013-1055.

Fletcher, J. S., \& Mullen, A. C. (Eds.). (2012). The SAGE handbook of mentoring and coaching in education. London: SAGE Publications.

Huberman, M. (1993). The lives of teachers. New York: Teachers College Press.

Ingersoll, R., Merrill, L., \& May, H. (2014). What are the effects of teacher education and preparation on beginning teacher attrition? Research Report (\#RR-82). Philadelphia: Consortium for Policy Research in Education, University of Pennsylvania.

Kelley, L. M. (2004). Why induction matters. Journal of Teacher Education, 55(5), 438-448.

OECD (2019). TALIS 2018 Results (Volume I): Teachers and School Leaders as Lifelong Learners, TALIS, OECD Publishing, Paris. Retrieved from https://doi.org/10.1787/1d0bc92a-en

Parker, A. M. (2010). Mentoring practices to keep teachers in school. International Journal of Evidence Based Coaching and Mentoring, 8(2), 111-123.

Petty, T., Good, A., \& Putman, S. M. (Eds) (2016). Handbook of research on professional development for quality teaching and learning. Hershey: IGI Global.

Toepoel, V. (2015). Doing surveys online. London, Thousand Oaks, New Delhi, Singapore: SAGE Publications. 